\title{
A role for corporate sustainability strategy in the Garden City
}

\author{
Lisa Palframan, James O. Jenkins, Xiaoqiang Zhang
}

\begin{abstract}
This paper discusses the response of the Letchworth Garden City Heritage Foundation to the sustainability agenda. The Heritage Foundation owns and manages the Letchworth Garden City Estate which includes housing, commercial premises, farms and community facilities within the world's first Garden City. The Heritage Foundation is adopting a sustainability strategy to actively manage its sustainability impacts. The paper discusses the rationale for a corporate sustainability approach rather than a corporate social responsibility or environmental management approaches. It explains the role of a sustainability management system in implementing a sustainability strategy and the opportunities that such strategies may offer organisations and their local communities.

Businesses are facing increasing scrutiny from their external stakeholders, including the communities within which they operate. Many organisations face significant challenges in developing an appropriate response. The adoption of a focused sustainability strategy can help organisations identify and manage their significant environmental, social and economic impacts more effectively and demonstrate their performance in these areas.
\end{abstract}

Key words: Sustainability performance, strategy development, garden city, stakeholder engagement.

$* * * * *$

\section{Introduction}

Most organisations are facing pressure to address their non-financial performance, both as a result of increasing regulation, especially in the environmental arena, and the changing expectations of external stakeholders. ${ }^{1}$

${ }^{2} 3$ The adoption of a sustainability strategy is one possible response to this challenge. Such a strategy can help organisations co-ordinate improvements to their environmental and social performance, while demonstrating to their stakeholders that business concerns extend beyond the bottom line. ${ }^{4}$ Furthermore, addressing these issues can have a significant impact on the financial performance of a company. ${ }^{5}$

The Letchworth Garden City Heritage Foundation (referred to hereafter as 'the Heritage Foundation') is the organisation that owns and 
manages the 2,200 hectare Letchworth Garden City Estate located in Hertfordshire, UK. Letchworth Garden City was built at the beginning of the $20^{\text {th }}$ century, delivering Ebenezer Howard's proposal for a new community which incorporated the best features of both town and country. ${ }^{6}$ The Heritage Foundation is a unique organisation, which inherited the Estate through an Act of Parliament and which operates outside the 'public' sector as an Industrial and Provident Society with Charitable Status. While some of the income from property and trading activities is reinvested in the estate, the Heritage Foundation is tasked with delivering a key feature of Howard's vision, that the majority of the annual profits from the Estate be ploughed back into the town. Through its six Charitable Objects (see Box 1), the Foundation funds and manages a day hospital, a museum, a community and entertainment centre, a minibus service, environmental improvements, education projects and town events. It also makes direct grants to clubs and individuals. Indeed since 1995 , some $£ 27 \mathrm{~m}$ has been given back to the town in this way. ${ }^{7}$

Box 1 - the Charitable Objects of the Letchworth Garden City Heritage Foundation, as set out in Schedule 2 of the Letchworth Garden City Heritage Foundation Act 1995

1. Promoting the preservation of buildings and other environmental features of beauty or historic interest within Letchworth Garden City.

2. Providing or assisting in the provision of facilities for the recreation or other leisure activity of the local community in the interests of social welfare with the object of improving their conditions of life.

3. Promoting the advancement of education and learning within Letchworth Garden City.

4. Promoting the relief of poverty and sickness within Letchworth Garden City.

5. Supporting any charitable organization having an office or branch in Letchworth Garden City.

6. Promoting any other charitable purposes for the benefit of the local community.

The responsibilities of the Heritage Foundation to deliver its Charitable Objects place it in a unique position to positively influence the development of the town towards becoming an exemplar $21^{\text {st }}$ century community. Socio-economic needs can be addressed in a way that also integrates environmental concerns such as resource efficiency and climate change. The breadth of the Heritage Foundation's responsibilities and 
business interests is significant. With over $70 \%$ of its annual income coming from property, it needs to ensure the environmental impacts of its offices, factories, shops, community buildings, orchards, allotments and agricultural land holdings are managed in accordance with recognised standards as a minimum. However, to be an effective leader in sustainability, the Heritage Foundation recognises that an exemplary approach to sustainability issues would enable it to credibly influence the practices of others.

To align its activities and aspirations, the Heritage Foundation is currently working with the University of Hertfordshire on a Knowledge Transfer Partnership Project to develop a corporate sustainability strategy. Acknowledging the high profile of the Heritage Foundation within the Garden City, this strategy will need to effectively respond to the issues that are important to key stakeholders in the community.

This paper explores the rationale for the Foundation to actively manage the sustainability implications of its activities. Section 2 explains the motivations for organisations to adopt a Corporate Sustainability (CS) approach, rather than narrower Environmental Management (EM) or alternatively focused Corporate Social Responsibility (CSR) approaches to respond to the sustainable development agenda. Section 3 explains the rationale for pursuing a corporate sustainability approach at the Heritage Foundation rather than other approaches. Section 4 discusses the challenge of implementation and proposes the use of a Sustainability Management System to enable this. Throughout the paper, we highlight the opportunities that may be open to organisations adopting a sustainability strategy for the first time, together with the benefits that affected local communities may experience.

\section{Corporate Sustainability and its relationship with other approaches to manage environmental responsibilities}

CS is a relatively recent concept, clearly linked to the emergence of the launch of the 1987 Brundtland Report Our Common Future which caused the concept of sustainability to become globally recognised. ${ }^{8}{ }^{9}$ The 1992 UNsponsored Rio Earth Summit further highlighted the role of businesses and corporations in achieving the sustainable development goal and it was at this time that the term Corporate Sustainability came into use. ${ }^{10}$ Governments identified how sustainable development was to be achieved in their own countries, for example the UK adopted its first sustainable development strategy in 1994, with further publications in 1999 and $2005 .^{11}$ Whilst the Government's early responses were primarily focused on environmental sustainability, this was followed by a strong emphasis on the economy and society with the term 'sustainable' being used to label strategies which were primarily addressing socio-economic priorities. ${ }^{12}$ The segregation of social, economic and environmental issues in the Government's four sustainable development objectives led to criticisms of "ambiguity, intellectual 
incoherence and a continuing failure to properly understand the essence of sustainable development". ${ }^{13}$ A more integrated approach is arguably at the centre of the most recent strategy. This aims to decouple economic growth from environmental impacts, through the pursuit of four shared priorities, each with a role for business (see Table 1).

Table 1: UK Sustainable Development Strategy shared priorities, ${ }^{14}$ highlighting implications for business.

\begin{tabular}{|c|c|}
\hline Priority & Business role / implications \\
\hline $\begin{array}{lll}\text { Sustainable consumption } & \text { and } \\
\text { production } & \end{array}$ & $\begin{array}{l}\text { Customer demands for higher } \\
\text { environmental standards need to be } \\
\text { met in the provision of goods and } \\
\text { services. The negative impacts of } \\
\text { rising resource consumption need to } \\
\text { be reduced. Product declarations or } \\
\text { labelling to be used to educate } \\
\text { customers. }\end{array}$ \\
\hline Climate change and energy & $\begin{array}{l}\text { Carbon dioxide emissions to be } \\
\text { reduced by improvements in } \\
\text { industrial efficiency. }\end{array}$ \\
\hline $\begin{array}{l}\text { Nature resource protection and } \\
\text { environmental enhancement }\end{array}$ & $\begin{array}{l}\text { Degraded land to be brought back } \\
\text { into safe and productive use through } \\
\text { a partnership approach. A scheme of } \\
\text { civil penalties for environmental } \\
\text { offences to be considered. }{ }^{17}\end{array}$ \\
\hline Sustainable communities & $\begin{array}{l}\text { Improved provision of employment } \\
\text { opportunities and support for self- } \\
\text { employment, } \quad \text { targeted } \\
\text { disadvantaged groups or areas. }{ }^{18}\end{array}$ \\
\hline
\end{tabular}

The varied interpretation of the sustainability concept has led to the fluidity of the definition of CS and consequent difficulties for practitioners in understanding what is involved in responding to this agenda. ${ }^{19}$ Two different definitions have been identified; one which links the concept to the ecological or environmental dimensions of business and another which takes a 'triple bottom line' view of environmental, social and economic issues. ${ }^{20}$ Some scholars describe the response to this latter interpretation by an organisation as $\mathrm{CSR}^{21}$ whilst others use the terms CS and CSR interchangeably. ${ }^{22}{ }^{23}$ It is argued that the two terms have different roots, with 
CSR being strongly anchored to social issues and CS combining a consideration of these with environmental and economic issues. ${ }^{24}$

One of the best known voluntary approaches to manage the interaction between business and the biophysical environment is the Environmental Management System (EMS). ${ }^{25}$ Management Systems represent a rational, process-based approach which continually checks and maintains compliance against pre-defined goals. ${ }^{26}$ While companies are urged to tailor their EMS to their own circumstances, the International Standards Organisation's ISO 14001 EMS standard defines the issues to be managed in narrow environmental terms (emissions, releases, waste, resource use, etc) ${ }^{27}$ Critics of the EMS approach have expressed concerns. They argue that it focuses on the management of effects arising from essentially unsustainable activities and that it is unable to deal with complex or ethical issues where the course of action needed to 'do the right thing' is unclear. ${ }^{28}{ }^{29}$ Therefore, how can organisations, like the Heritage Foundation, select an approach that allows them to co-ordinate improvements to their environmental and social performance, while demonstrating to their stakeholders that business concerns extend beyond the bottom line? This question is of central importance to this paper and is one upon which the next section focuses.

\section{Selecting a suitable approach for the Heritage Foundation}

It is clear from the discussion above that organisations looking to actively address their non-financial performance are faced with a range of possible options in terms of their overall approach. However, smaller organisations may lack the technical skills and knowledge to assess the suitability of different environmental and sustainability tools for their particular circumstances, which may result in them not addressing the issue at all or experiencing delays and further expense when they do take action. ${ }^{30}$

The Heritage Foundation has found itself in this position in recent years, recognising the need to more actively manage the environmental impacts of its own operations while realising the potential role it could play as an environmental leader in the community. Having implemented a recycling initiative across its operations, the organisation required advice on prioritising and addressing waste management more generally, alongside energy and transport. A series of environmental reviews revealed multiple opportunities to improve the management of individual issues, whilst highlighting the need for a more strategic approach across the organisation. In particular, there was limited monitoring of resource use and individual business units needed to be motivated and incentivised to reduce the impacts of their operations in a consistent manner. A strategic approach was needed to communicate the commitment of senior management towards environmental improvement and to promote action from employees, leading to a cultural change internally. ${ }^{31}$ Communication of the strategy and its 
outcomes, once delivered, would also strengthen stakeholder relations externally. $^{32}$

While the use of a strategic environmental management approach to improvement, such as an EMS, would have enabled the Heritage Foundation to control its environmental risks and manage its key aspects, a CS approach offered greater opportunity. For instance, the charitable objects which govern its activities have a strong social justice theme. As a major property owner, it has considerable influence over the economic development of the town, having recently embarked upon major reinvestment in the town centre. At the same time, the Foundation recognised a need to ensure that the way these activities were delivered was fully aligned to sustainable development priorities (see Table 1) and to improve its relationship with local stakeholders, particularly the general public. Since the catalyst for this project had been primarily an environmental one, a CSR approach was dismissed. The Heritage Foundation's direct activities and market are limited to the boundaries of Letchworth Garden City Estate. CSR is perceived by many stakeholders as more relevant to multinational companies and concerned with human rights. ${ }^{33}$ This perception may have limited people's understanding of what the Heritage Foundation is trying to achieve.

As a result, the Heritage Foundation is operationalising CS through the adoption of a comprehensive sustainability strategy, addressing environmental, economic and social dimensions, their impacts and interrelationships. $^{34}$ The strategy is being designed to reflect senior management's decisions about how sustainable the organisation ought to be and the resources available to put these principles into practice. ${ }^{35}$ Sustainability strategies can be categorised according to their focus and the standards of sustainability they aim to pursue (see Table 2 ). ${ }^{36}$

Table 2: Typology of corporate sustainability strategies. ${ }^{37}$

\begin{tabular}{|l|l|}
\hline Type & Description \\
\hline Introverted & $\begin{array}{l}\text { Risk mitigation strategy: focus on legal and other } \\
\text { external standards concerning environmental and social } \\
\text { aspects in order to avoid risks for the company }\end{array}$ \\
\hline Extroverted & $\begin{array}{l}\text { Legitimating strategy: focus on external relationships, } \\
\text { license to operate }\end{array}$ \\
\hline Conservative & $\begin{array}{l}\text { Efficiency strategy: focus on eco-efficiency and cleaner } \\
\text { production }\end{array}$ \\
\hline Visionary & $\begin{array}{l}\text { Holistic sustainability strategy: focus on sustainability } \\
\text { issues within all business activities: competitive } \\
\text { advantages are derived from differentiation and } \\
\text { innovation, offering customers and stakeholders unique } \\
\text { advantages }\end{array}$ \\
\hline
\end{tabular}


While these categories reflect increasing maturity of the strategies, the Heritage Foundation is initially aiming to adopt a transformative extroverted strategy, to positively influence basic conditions for sustainability, such as those defined by the Natural Step Framework. ${ }^{38} 3940$ This type of strategy enables the organisation to become a champion of sustainable development in society, whilst also ensuring that internal sustainability issues are fully dealt with. ${ }^{41}$ With respect to the project, an extensive quantitative baseline review has already been conducted to investigate the significance of these issues, which is enabling identification of the areas in need of improvement prior to the strategy being drawn up. A stakeholder engagement exercise is currently under way, enabling the external expectations of the Heritage Foundation's role in sustainable development to be fully understood and where appropriate, reflected in the development and implementation of the strategy.

\section{Addressing the challenge of implementation}

Once a sustainability strategy has been developed and adopted by an organisation, a major challenge of a policy response is to ensure it is implemented effectively throughout the organisation. ${ }^{42}$ This requires that sustainability values are embedded into the organisation's core business strategies and processes. ${ }^{43}$ It requires changes in the way operational activities are carried out by staff to be sustained over time until they become part of the organisation's culture. ${ }^{45}$ To this end, a Sustainability Working Group has been meeting within the Heritage Foundation since 2008. This is chaired by the Property Director and includes representatives from the Property, Marketing and Finance departments. This group has played a major role in identifying emerging issues relevant to the different work areas, implementing the recommendations from the Environmental Reviews and progressing projects such as a workplace travel survey of staff.

This approach represents recognised good practice in helping to raise the profile of sustainability issues internally. ${ }^{46}$ However, it is only one part of the implementation process. A sustainability management system (SMS) will be used to ensure that the strategy is put into practice throughout the organisation. ${ }^{48}$ An SMS may be considered as a mature standard EMS that has been expanded to consider broader sustainability issues. ${ }^{49}$ Although the Heritage Foundation does not currently operate an EMS, a bespoke SMS will be put into place which implements the strategy through yearly action plans designed to achieve specific objectives and targets. ${ }^{50}$ Initial sustainability performance indicators have already been proposed following the baseline review although these will be adapted in response to internal and external stakeholder input. ${ }^{51}$ Progress against these indicators will be 
monitored and reported. Arrangements for resourcing, responsibilities, staff training and communication are currently being made.

Concerns have been expressed that while management systems can help organisations to 'do things right the first time', ie specific actions have been achieved, they cannot help organisations in their quest to 'do the right things', ie adopt appropriate values. ${ }^{52}$ Therefore, by firstly carrying out a thorough baseline review, initiating stakeholder engagement and adopting a sustainability strategy, it is argued that the Heritage Foundation will be able to rely on a management systems approach to continually check that 'the right things' for sustainability are being done. This means that values and actions can be aligned and year-on-year progress will be made.

\section{Conclusion}

The Heritage Foundation is developing a sustainability strategy that will guide its current and future activities. This approach is enabling it to identify and manage the key environment, social and economic impacts of its activities, while in the future maximising the positive influence of its unusual position and enabling it to take a leadership role in sustainability within Letchworth Garden City. While the Heritage Foundation is a unique organisation, with special responsibilities towards the community of Letchworth Garden City, the approach taken is applicable to other organisations.

Businesses have a vital role in enabling society to move towards a more sustainable future. ${ }^{53}$ Issues such as climate change and resource consumption need to be tackled effectively in a way which addresses issues of equity and opportunity for all. Implementing a sustainability strategy through the use of a sustainability management system will enable organisations to identify and address the most significant sustainability issues they face. It enables organisations to make progress year on year, reducing their environmental impacts such as energy and resource use, while enhancing their community contribution in a manner which is aligned with sustainable development principles. Furthermore, this approach demonstrates that sustainability issues are a corporate priority. High profile, forward thinking organisations must respond positively to a growing body of vocal stakeholders demanding their contribution in the transition towards a more sustainable society. 
${ }^{1} \mathrm{~J}$ Elkington, 'Enter the triple bottom line', in The triple bottom line: does it all add up? Assessing the sustainability of business and CSR, A Henriques and J Richardson (eds), Earthscan, London, 2004, p. 7.

${ }^{2} \mathrm{R}$ Isaksson and U Steimle, 'What does GRI-reporting tell us about corporate sustainability?', The TQM Journal, vol, 21, number 2, 2009, p. 168.

${ }^{3} \mathrm{U}$ Steger, 'Building a business case for corporate sustainability' in Managing the Business Case for Sustainability, S Schaltegger \& M Wagner (eds), Greenleaf Publishing, Sheffield, 2006, pp. 423-427.

${ }^{4} \mathrm{M}$ Epstein, 'Making sustainability work: best practices in managing and measuring corporate social, environmental and economic impacts', Greenleaf Publishing Sheffield, 2008, pp. 249-261.

${ }^{5}$ S Schaltegger and M Wagner, 'Managing and measuring the business case for sustainability', in Managing the Business Case for Sustainability, S Schaltegger and M Wagner (eds), Greenleaf Publishing, Sheffield, 2006, pp. $1-27$.

${ }^{6}$ E Howard, Garden cities of tomorrow, $3^{\text {rd }}$ ed., Dodo Press, London, 2009.

${ }^{7}$ A. Howard, personal communication, 4 June 2010.

${ }^{8}$ M Linnenluecke and A Griffiths, 2009. 'Corporate sustainability and organizational culture'. Journal of World Business, in press.

9 I Montiel, 'Corporate social responsibility and corporate sustainability: separate pasts, common futures', Organization \& Environment, vol. 21, issue 3, 2008, pp. 245-269.

${ }_{10}^{10}$ Ibid., p. 254.

${ }^{11}$ HM Government, Securing the future: delivering the UK sustainable development strategy, HMSO, London, 2005, p.13.

${ }^{12}$ D Russel, 'The United Kingdom's sustainable development strategies: leading the way or flattering to deceive?', European Environment, vol. 17, 2007, pp. 189-200.

${ }^{13}$ J Porritt, 'Locating the Government's bottom line', in The Triple Bottom Line: does it all add up? Assessing the sustainability of business and CSR, A Henriques, \& J Richardson (eds), Earthscan, London, 2004, pp. 59-69.

${ }^{14}$ HM Government, p. 17.

${ }^{15}$ Ibid., p. 46.

${ }^{16}$ Ibid., p. 81.

${ }^{17}$ Ibid., pp. 111-112.

${ }^{18}$ Ibid., pp. 136-138.

19 J Esquer-Peralta, L Velaquez and N Munguia, 'Perceptions of core elements for sustainability management systems', vol. 46, no. 7, 2008, p. 1027.

${ }^{20}$ Montiel, p. 254.

${ }^{21}$ Linnenluecke and Griffiths, p. 2. 
22 A Azapagic, 'Systems approach to corporate sustainability: a general management framework', Process Safety and Environmental Protection, vol. 81, issue 5, 2003, pp. 303-316.

${ }^{23}$ M Van Marrewijk, 'Concepts and definitions of CSR and corporate sustainability: between agency and communion', Journal of Business Ethics, vol. 44, 2003, p. 102.

${ }^{24}$ Montiel, pp. 257-259.

$25 \mathrm{R}$ Welford, 'Environmental issues and corporate environmental management', in Corporate environmental management 1: systems and strategies, $2^{\text {nd }}$ ed, Welford (ed), Earthscan, London, 1998, pp. 1-12.

${ }^{26} \mathrm{G}$ Zwetsloot, 'From management systems to corporate social responsibility', Journal of Business Ethics, vol. 44, 2004, pp. 202-203.

27 International Standards Organization, 'ISO 14001 Environmental management system: requirements with guidance for use', International Standards Organization, Geneva, 2004, pp.11-12.

28 J MacDonald, 'Strategic sustainable development using the ISO 14001 standard', Journal of Cleaner Production, vol. 13, 2005, p. 631.

${ }^{29}$ G Zwetsloot, pp. 203-206.

30 R Hillary, 'Environmental management systems and the smaller enterprise', Journal of Cleaner Production, 12, 2004, pp. 561-569.

${ }^{31}$ B Daily and S Huang, 'Achieving sustainability through attention to human resource factors in environmental management', International Journal of Operations \& Production Management, vol. 21, number 12, 2001, pp. 15391552.

${ }^{32} \mathrm{R}$ Jackson, 'Environmental and sustainability reporting', in The sustainable enterprise: profiting from best practice, S Reuvid (ed), Simmons \& Simmons, London and Philadelphia, 2006, p. 32.

${ }^{33}$ Castka et al, p. 42.

$34 \mathrm{R}$ Baunmgartner and D Ebner, 'Corporate sustainability strategies: sustainability profiles and maturity levels', Sustainable Development, vol. 18, 2010, p.77.

${ }^{35}$ Epstein, p. 64.

${ }^{36}$ Baumgartner and Ebner, p. 81.

${ }^{37}$ Ibid., p. 78.

${ }^{38}$ System conditions for sustainability: In the sustainable society, nature is not subject to systematically increasing 1: concentrations of substances extracted from the Earth's crust; 2 . Concentrations of substances produced by society; 3. Degradation by physical means; 4 . And in that society, human needs are met worldwide. Taken from K-H Robért, Schmidt-Bleek, J Aloisi de Larderel, G Basile, J Jansen, R Kuehr, P Price Thomas, M Suzuki, P Hawken, M Wackermagel, 'Strategic sustainable development — selection, 
design and synergies of applied tools', Journal of Cleaner Production, 10, 2002, pp. 198-199.

${ }^{39}$ Baumgartner and Ebner, p. 84.

${ }^{40}$ Ibid.

${ }^{41}$ K-H Robért, 'Tools and concepts for sustainable development, how do they relate to a general framework for sustainable development and to each other?', Journal of Cleaner Production, vol. 8, 2000, pp. 243-247.

${ }^{42} \mathrm{M}$ Hill and P Hipe, Implementing Public Policy, Sage Publications, London, 2000

${ }^{43}$ Azapagic, p. 304.

44 T Hahn and M. Scheermesser, 'Approaches to Corporate Sustainability among German Companies', Corporate Social Responsibility and Environmental Management, vol. 13, 2006, p. 160.

${ }^{45}$ Linnenluecke \& Griffiths, p. 2.

${ }^{46} \mathrm{C}$ Beard and S Rees, 'Green teams and the management of environmental change in a UK county council', Environmental Management and Health, vol. 11, issue 1, 2000, p.37.

${ }^{47}$ N Govindarajulu and B Daily, 'Motivating employees for environmental improvement', Industrial Management \& Data Systems, vol. 104, Issue 4, 2004 , p. 367.

48 Azapagic, p. 304.

${ }^{49} \mathrm{~S}$ Emilsson and O Hjelm, 'Towards sustainability management systems in three Swedish local authorities', Local Environment, vol. 14, issue 8, 2009, p. 722.

${ }^{50}$ Azapagic, p. 310.

51 J Keeble, S Topiel and S Berkeley, 'Using indicators to measure sustainability performance at a corporate and project level', Journal of Business Ethics, vol. 44, 2003, p. 151.

${ }^{52}$ Zwetsloot, pp. 202-204

${ }^{53}$ HM Government, p. 46.

\section{Bibliography}

Azapagic, A., Systems approach to corporate sustainability: a general management framework. Process Safety and Environmental Protection, vol. 81, number 5, 2003, pp. 303-316.

Bansal, P., Evolving sustainably: A longitudinal study of corporate sustainable development. Strategic Management Journal, vol. 26, issue 3, 2005, pp. 197-218. 
Baumgartner, R. and Ebner, D., 'Corporate sustainability strategies: sustainability profiles and maturity levels', Sustainable Development, vol. 18, 2010 , p.77.

Beard, C. and Rees, S. 'Green teams and the management of environmental change in a UK county council', Environmental Management and Health, vol. 11 , issue 1,2000, p.37.

Castka, P., Balzarova, M., Bamber, C. \& Sharp, J. How can SMEs effectively implement the CSR agenda? A UK case study perspective. Corporate Social Responsibility and Environmental Management, vol. 11 2004, pp. 140-149.

Daily, B. and Huang, S., 'Achieving sustainability through attention to human resource factors in environmental management', International Journal of Operations \& Production Management, vol. 21, number 12, 2001, pp. 1539-1552.

Elkington, J., 'Enter the triple bottom line', in The triple bottom line: does it all add up? Assessing the sustainability of business and CSR, A Henriques and J Richardson (eds), Earthscan, London, 2004, p. 7.

Emilsson, S. and Hjelm, O., 'Towards sustainability management systems in three Swedish local authorities', Local Environment, vol. 14, issue 8, 2009, p. 722

Epstein, M., 'Making sustainability work: best practices in managing and measuring corporate social, environmental and economic impacts', Greenleaf Publishing Sheffield, 2008, pp. 249-261.

Esquer-Peralta, J., Velaquez, L., and Munguia, N.,'Perceptions of core elements for sustainability management systems’, vol. 46, no. 7, 2008, p. 1027.

Govindarajulu, N. and Daily, B., 'Motivating employees for environmental improvement', Industrial Management \& Data Systems, vol. 104, Issue 4, 2004, p. 367.

Hahn, T. and Scheermesser, M., 'Approaches to Corporate Sustainability among German Companies', Corporate Social Responsibility and Environmental Management, vol. 13, 2006, p. 160. 
HM Government, Securing the future: delivering UK sustainable development strategy. HMSO, London, 2005.

Hill, M and Hipe, P Implementing Public Policy, Sage Publications, London, 2000 .

Hillary, R., 'Environmental management systems and the smaller enterprise', Journal of Cleaner Production, 12, 2004, pp. 561-569.

Howard, E., Garden cities of tomorrow, $3^{\text {rd }}$ ed., Dodo Press, London, 2009.

International Standards Organization, 'ISO 14001 Environmental management system: requirements with guidance for use', International Standards Organization, Geneva, 2004, pp.11-12.

Isaksson, R. and Steimle, U., 'What does GRI-reporting tell us about corporate sustainability?', The TQM Journal, vol. 21, number 2, 2009, p. 168.

Keeble, J., Topiel, S. and Berkeley, S.,'Using indicators to measure sustainability performance at a corporate and project level', Journal of Business Ethics, vol. 44, 2003, p. 151.

Linnenluecke, A. \& Griffiths, A.,. Corporate sustainability and organizational culture. Journal of World Business, 2009 (in press).

MacDonald, J., 'Strategic sustainable development using the ISO 14001 standard', Journal of Cleaner Production, vol. 13, 2005, p. 631.

Montiel, I., Corporate social responsibility and corporate sustainability: separate pasts, common futures. Organization \& Environment, vol. 21, number 3, 2008, pp. 245-269.

Porritt, J., Locating the Government's bottom line. In Henriques, A. \& Richardson, J. (eds), The Triple Bottom Line: does it all add up? Assessing the sustainability of business and CSR. Earthscan, London, 2003.

Robért, K-H., 'Tools and concepts for sustainable development, how do they relate to a general framework for sustainable development and to each other?', Journal of Cleaner Production, vol. 8, 2000, pp. 243-247. 
Robért, K-H., Schmidt-Bleek, Aloisi de Larderel, J., Basile, G., Jansen, J., Kuehr, R., Price, P., Suzuki, T., Hawken, P. and Wackermagel, M., 'Strategic sustainable development - selection, design and synergies of applied tools', Journal of Cleaner Production, 10, 2002, pp. 198-199.

Russel D., 'The United Kingdom's sustainable development strategies: leading the way or flattering to deceive?', European Environment, vol. 17, 2007, pp. 189-200.

Schaltegger, S. and Wagner M.,, 'Managing and measuring the business case for sustainability', in Managing the Business Case for Sustainability,

Schaltegger and M Wagner (eds), Greenleaf Publishing, Sheffield, 2006, pp. $1-27$.

Van Marrewijk, M., 'Concepts and definitions of CSR and corporate sustainability: between agency and communion', Journal of Business Ethics, vol. 44, 2003, p. 102.

Welford, R., 'Environmental issues and corporate environmental management', in Corporate environmental management 1: systems and strategies, $2^{\text {nd }}$ ed, Welford (ed), Earthscan, London, 1998, pp. 1-12.

Zwetsloot, G., 'From management systems to corporate social responsibility', Journal of Business Ethics, vol. 44, 2004, pp. 202-203.

Dr James. O. Jenkins and Lisa Palframan both research and teach environmental management at the University of Hertfordshire, UK. Xiaoqiang Zhang is Sustainability Advisor / KTP Associate at the Letchworth Garden City Heritage Foundation.

This Partnership received financial support from the Knowledge Transfer Partnership programme (KTP). KTP aims to help businesses improve their competitiveness and productivity through the better use of knowledge, technology and skills that reside within the UK Knowledge Base. KTP is funded by the Technology Strategy Board along with the other government funding organisations. 